GOS will offer to its members a service that will match the library's holdings against the set to see which items they do or do not hold. It beats tearing up the pages and having a student assistant look each one up in the card catalog!

ACRL published ACRL University Library Statistics, 1987-88, and Collection Development Policies for College Libraries, CLIP Note \#II.

\section{Strategic management directions}

Staff worked with ACRL president Joe Boissé and Budget and Finance Committee chair Linda
Piele on an information sheet about the dues increase to be voted on by members.

JoAn Segal continued to work with other division leaders and staff and with ALA leaders and staff on a new Operating Agreement between ALA and divisions. Data collected will help divisions assess the financial impact of proposed changes.

Ballots were prepared for the Spring elections.

Sheryl Stephens has accepted a position with the American Bar Association effective in midApril.-JoAn S. Segal, ACRL Executive Director.

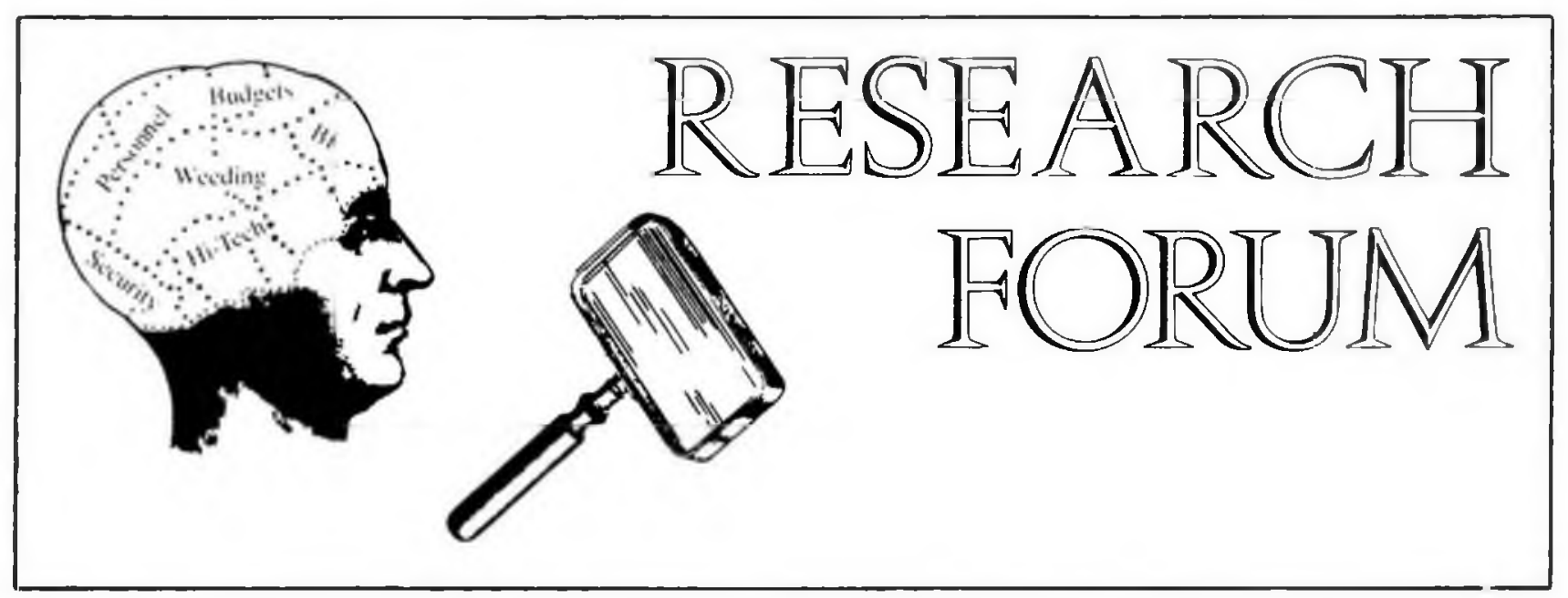

\title{
Relating research agendas
}

\author{
By Bonnie Gratch \\ Director of Information Services \\ Bowling Green State University
}

\begin{abstract}
Editor's Note: The "Research Forum" column was begun several years ago to encourage research ideas, explore methodology, and report on research in progress. Recently Bonnie Gratch, a member of the C\&RL News Editorial Board, offered to serve as editor of this column and follow the progress of ACRL's Research Committee as they develop a Research Agenda for the Association. Anyone wishing to submit short or medium-sized, relatively informal items for possible inclusion in this column may write directly to: Bonnie Gratch, Research Forum Editor, William T. Jerome Library, Bowling Green State University, Bowling Green, $\mathrm{OH}$ 43403-0170.
\end{abstract}

Recently a number of organizations and committees have been engaged with developing research issues and agendas for librarianship/information science. The September 1988 College and Research Libraries contains an editorial by Charles
Martell which describes the research formulating initiatives of the Association of Research Libraries, the Council on Library Resources, and ALA's Office for Research. The January 1989 American Libraries contains a news item which alerts its readership to a monumental study carried out by the U.S. Department of Education's Office of Library Programs in 1986-1987, of which two volumes of the report titled, Rethinking the Library in the Information Age-Issues in Library Research: Proposals for the Nineties, have recently been published.

The process employed in studying research issues and generating Rethinking the Library is a testament to excellent research methodology, and at the ACRL Research Committee's Midwinter meeting in Washington, committee members and observers were privileged to hear Anne Mathews, director of Library Programs, U.S. Department of Educa- 
tion, describe the numerous steps and activities in this 18-month project. ACRL's Research Committee members are particularly interested in this impressive report, since they have been studying research issues and areas for academic librarianship for over two years, and are expected to issue a research agenda in late 1989.

With at least four completed and/or draft documents to compare, the following research areas and issues are examples which may be particularly important ones, since they are included in at least two of the four documents. ${ }^{*}$ The few questions listed under each broad research area are only a sampling of the several questions contained in some of these documents.

1. Access to Information-Technological, Physical, and Economic Aspects. What is the impact of changing information technology on user behavior? How does the physical layout affect information access? What is the impact of fees upon access for academic libraries and their users? Does library technology support resources and enhance learning and research or does it pose a barrier to access?

2. Information Needs/Users. How can we learn more about user needs? What will the needs of library users be in 10 years? How do information needs vary by discipline or aggregates of user groups?

3. Libraries and Education. In the complex information environment, what are the appropriate

*My observations are based on ARL's "Research Questions of Interest to ARL"; the Council on Library Resources' series of research question topics (both outlined in the September C URL); Rethinking the Library in the Information Age, Volume I; and a January 1989 draft "Subject Outline for an ACRL Research Agenda" prepared by the ACRL Research Committee. present and future roles of libraries and librarians, especially in relation to teaching? How can we achieve information literacy?

4. Structure of Information Systems. How can we apply results of artificial intelligence, text processing, and expert systems research to improve retrieval of information? Do large files of machinereadable information and new processing capabilities affect the substance as well as the methodology of research? How could academic libraries best respond to the increase in electronic publishing?

5. Resource Sharing. Does competition among bibliographic utilities benefit research libraries? What are the pitfalls? How do you measure (and what are the indicators) changed behavior arising from cooperative resource sharing activities?

6. Role of the Public Services Librarian. What is and will be the role of the librarian as intermediary? What are and will be appropriate ways of organizing reference service?

7. Preservation. What criteria should be considered when identifying materials for preservation? What factors need to be considered when evaluating new technology for application to preservation activities?

8. Library Funding and Economics. What is the correlation between library support and outcomes, such as university quality rates, test scores, research productivity, etc.? What is the impact of scholarly publishing pricing policies on research?

9. Education and Training of Librarians. Is there a core curriculum? How effective and wellutilized are continuing education and on-the-job training activities for librarians? What is the profile of the current library/information science school student body versus the desired student body?

\section{Fulbright Program with the United Kingdom, 1990-91}

The Fulbright Commission in London has announced the availability of an award for a practicing librarian to pursue professional work in the United Kingdom at a degree-awarding institution or major research library. The competitive award is being made available under the Fulbright Scholar Program to provide an opportunity for librarians to broaden their professional perspective and enhance cross-cultural skills and insights. The purpose of the award is to promote the exchange of ideas between library staff in the U.S. and the U.K. and to enable participants to acquire knowledge and experience of library work in a different setting.

- Applicants must be librarians, library administrators, or archivists at four-year colleges and universities or major research libraries outside of higher education. Proposals from library science educators are not appropriate to this award, which is designed for full-time practitioners.

- Applicants must hold U.S. citizenship and a minimum of five years continuous professional experience is also required. An MLS degree is expected, though extensive professional service may in some cases be substituted for the degree. The program is designed for mid-career professionals who hold positions appropriate to implementing new ideas and insights gained from the exchange experience.

- Applicants are responsible for arranging a work affiliation with a university library, major research library, or national library in the United Kingdom. A list of British institutions that are eligible for participation in the award is available upon request. A letter of invitation must be submitted with the application. 
- Projects may be single purpose or comparative in scope; they may be investigative or operational in focus. Professional work attachments should involve some consideration of relevant issues of a larger magnitude than basic employment abroad. Proposals that have a pragmatic bearing on issues of common concern to librarians in the U.S. and U.K. are particularly welcome.

- Awards are for a minimum duration of three months and grantees are expected to be paid leave of absence from their home institution. The grantee will receive a fixed grant of approximately 2,500 British pounds, paid in pounds sterling, to cover travel and other expenses. 1989.

- Deadline for applications is September 15,

For more information and a list of libraries approved for affiliation, please call or write Steven Blodgett or Michael Doyle of the Council for International Exchange of Scholars, 3400 International Drive, N.W., Suite M-500, Washington, DC 20008-3097; (202) 686-6239.

\section{ACRL programs in Dallas}

\section{This year's conference programs feature invisible users, designer genes, and infostructure.}

\section{Anthropology and Sociology Section}

“Access to Anthropological Field Notes: Preservation, Collection and Ethical Issues" (Sunday, June 25, 9:30 a.m.-12:30 p.m.) will feature a panel of four speakers: Anthony Seeger, curator of the Folkways Collection, Smithsonian Institution; Mary Elizabeth Ruwell, archivist, Northeast Document Conservation Center; Kathleen T. Baxter, reference archivist for the National Anthropological Archives, Smithsonian Institution; and Mark Handler, librarian, Stanford Law Library.

\section{Art Section}

"Networks for Cooperation in the Arts" (Sunday, June 25, 2:00-5:00 p.m.) will explore the state-of-the-art of cooperative ventures among libraries serving the arts. The origin, purpose, membership, scope, governance, accomplishments, and facilities of several major cooperatives representing different disciplines will be featured: "Getting Our Act Together: The Performing Arts Libraries Network of Greater Los Angeles," Joan D. Kunselman, UCLA; "Concerning A\# Music Cooperative (Boston Area Music Libraries),"William F. Coscorelli, University of Georgia; "A Portrait of Collaboration and Confluence in the Fine Arts
(Washington Art Library Resources Committee)," Margaret Culbertson, University of Houston; and "New Bindings for Old Libraries: The Philadelphia Area Consortium of Special Collections Libraries," Kathleen Reed, Drexel University.

\section{Bibliographic Instruction Section}

"Invisible Users/Visible Technology: BI Beyond the Library" (Sunday, June 25, 2:00-5:30 p.m.), will explore the current and future instructional needs of invisible users of online catalogs and other databases, and the challenges, choices and opportunities BI librarians will face in meeting those needs. The program will open with the presentation of the Miriam Dudley BI Librarian of the Year Award. Speakers will include Sally Kalin, Pennsylvania State University; Betsy Baker, Northwestern University; and William Mischo, University of Illinois at Urbana-Champaign. Following the program there will be an orientation to the Bibliographic Instruction Section for new and prospective members.

\section{Black Studies Librarianship Discussion Group}

“Authors/Publishers: Barriers to Access” (Satur- 